\title{
The Islamic counseling construction in da'wah science structure
}

\author{
Agus Riyadi ${ }^{1 *}$, Hendri Hermawan Adinugraha ${ }^{2}$ \\ ${ }^{1}$ Universitas Islam Negeri Walisongo, Semarang, Indonesia \\ ${ }^{2}$ Institut Agama Islam Negeri Pekalongan, Indonesia \\ Email: agus.riyadi@walisongo.ac.id
}

\begin{abstract}
Purpose - The purpose of this study was to describe the Islamic counseling construction in the da'wah science structure.

Method - This study used a qualitative descriptive analysis especially library research. The researchers examined the amount of literature relevant to the problem in this study.

Result-The results showed that guidance and counseling are disciplines occupies a specific area of the human relationship in terms of the relationship that needs and helps each other. Relationship patterns like this, in reality, are built by a person or group of people based on different motives and values. One of them is the foundation of religious spirit in the form of awareness of the sacred mission as the basis for one's activities in establishing relationships with other people. On this basis, the guidance and counseling activities are very appropriate when it is integrated with Islamic da'wah activities so that it becomes clear that the construction of Islamic guidance and counseling is in the structure of da'wah science.

Implications - This study can be used to improve the skills performance of the Islamic counseling construction in the da'wah science structure.
\end{abstract}

Originality - This research is the first study that used literature deeply about AlNadzariyah Al-Syumuliyah Al-Qur'aniyah in da'wah science.

Keywords: Guidance, Islamic counseling, da'wah science.

For citation: Riyadi, A \& Adinugraha, H. H. (2021). The Islamic counseling construction in da'wah science structure. Journal of Advanced Guidance and Counseling. 2(1). 11-38. https://doi.org/10.21580/jagc.2021.2.1.6543.

*Corresponding author: Agus Riyadi (agus.riyadi@walisongo.ac.id), Universitas Islam Negeri Walisongo, Jl. Walisongo No.3-5, Tambakaji, Kec. Ngaliyan, Kota Semarang, Jawa Tengah, Indonesia, 50185. 
Agus Riyadi \& Hendri Hermawan Adinugraha

JAGC $\mid 12$

\begin{abstract}
Abstrak
Tujuan - Tujuan penelitian ini adalah untuk mendeskripsikan konstruksi konseling Islam dalam struktur ilmu dakwah.

Metode - Penelitian ini menggunakan analisis deskriptif kualitatif khususnya penelitian kepustakaan. Peneliti mengkaji sejumlah literatur yang relevan dengan masalah dalam penelitian ini.

Hasil - Hasil penelitian menunjukkan bahwa bimbingan dan konseling menempati wilayah tertentu dari hubungan manusia dalam hal hubungan yang saling membutuhkan dan membantu. Pola hubungan seperti ini pada kenyataannya dibangun oleh seseorang atau sekelompok orang berdasarkan motif dan nilai yang berbeda. Salah satunya adalah landasan spirit keagamaan berupa kesadaran akan misi suci sebagai landasan aktivitas seseorang dalam menjalin hubungan dengan orang lain. Atas dasar itulah maka kegiatan bimbingan dan konseling sangat tepat bila dipadukan dengan kegiatan dakwah Islam sehingga menjadi jelas bahwa konstruksi bimbingan dan konseling Islam berada dalam struktur ilmu dakwah.

Implikasi - Penelitian ini dapat digunakan untuk meningkatkan kinerja keterampilan konstruksi konseling Islam dalam struktur ilmu dakwah.

Originalitas - Penelitian ini merupakan penelitian pertama yang menggunakan literatur secara mendalam tentang Al-Nadzariyah Al-Syumuliyah Al-Qur'aniyah dalam ilmu dakwah.
\end{abstract}

Kata kunci: Bimbingan, konseling Islam, ilmu dakwah.

\title{
Introduction
}

Da'wah is every effort to reconstruct a society that still contains elements of ignorance to become an Islamic society (Rais, 1999). Therefore Zahrah emphasizes that Islamic da'wah begins with amar ma'ruf and nahi munkar, so there is no other logical interpretation of the meaning of amar ma'ruf except to completely believe in Allah, namely to deal with the substance of His nature (Zahrah, 1994). Furthermore, in essence, Islamic preaching is the actualization of faith (theological) which is manifested in a system of human activities in the field of society which is carried out regularly to influence the way humans feel, think, behave, and act on the plains of individual and socio-cultural reality in the context of striving for the realization of Islamic teachings in all aspects of life by using certain methods (Achmad, 1983; Sanusi, 1980; Arifin, 2008; Hafidhuddin, 2009). 
One of the studies in the da'wah science is Islamic guidance and counseling. Islamic guidance and counseling is a derivative of the da'wah bil-qaul which is carried out individually or in small groups. Academically, studies on Islamic guidance and counseling have not received complete and comprehensive attention. The existing guidance and counseling are dominated by guidance and counseling from the West. Whereas guidance and counseling originating from the West have essential and fundamental differences from Islamic guidance and counseling. Guidance and Counseling in the West are more oriented towards self, relations with others and with the natural environment, as well as guidance and counseling for the present. Guidance and counseling in the West do not relate to a vertical relationship with God (faith), worship behavior, noble morals, and life in the hereafter (Musnamar, 1992).

These differences, of course, have far-reaching consequences, regarding the basis, objectives, materials, and qualifications of mentors and counselors, toward the output that they want to reach. If this is allowed to develop and to be anticipated, it will have a negative impact on the development of Islamic da'wah in society. In addition, the concept of guidance and counseling that exists in the community often experiences overlapping between guidance and counseling, and even refraction occurs. Guidance is widely interpreted as tabligh, broadcasting, and coaching. Likewise, the meaning of counseling or extension is widely interpreted in the direction of information such as agricultural extension, family planning extension, and so on. The occurrence of this refraction is understandable considering that the meaning of guidance and counseling, especially Islam, has not been developed completely and clearly.

Based on the ontological study, between Islamic counseling and other counseling disciplines, there is no significant difference in the ontological basis. Between the two, it is only distinguished by the aspect of the status of the counselor and the spirit of morality which is used as an umbrella for counseling activities (Komarudin, 2015). If people look at the urgency of guidance and counseling in the community, it seems that there is no need to doubt it. Guidance and counseling is a need that is always present in the midst of society. Moreover, for the Indonesian people who are experiencing a multidimensional crisis and 
Agus Riyadi \& Hendri Hermawan Adinugraha

facing the development of the global community, the need for guidance and counseling cannot be negotiated. For this reason, Islam as the majority religion needs to formulate a clear and functional concept of Islamic guidance and counseling. As a comprehensive and universal religion, Islam can answer and fulfill these demands. In this case, of course, it is necessary to study in depth from the foundation of Islam, namely the Qur'an. The Qur'an which functions as guidance, syifa, differentiator, and mercy for humans will not leave humans in confusion. Because in creating humans, Allah has given a signal to humans to use reasons in understanding the kauniyah verses and qauliyah verses. Based on this foundation, it is important to examine the construction of Islamic guidance and counseling in the structure of da'wah science.

\section{Research Method}

This study used qualitative descriptive analysis especially library research. The researchers examined the amount of literature relevant to the research problem. According to Bogdan and Taylor (1975), qualitative methodology is a research procedure that produces descriptive data in the form of written or spoken of people and observed behavior.

Creswell (2013) explains that qualitative research begins with assumptions and the use of an interpretive or theoretical framework that shapes or influences the study of research problems related to the meaning conducted by individuals or groups on a social or human problem. To study this problem, qualitative researchers use a cutting-edge qualitative approach to research, collect the data in a natural environment that is sensitive to people and research sites, analyze data that is both inductive and deductive, and use the formation of patterns or themes. The final written report or presentation includes voices from participants, reflexivity from the researcher, descriptions and interpretations of the research problem, and their contributions to the literature that calls for change.

The conclusion that can be drawn from the opinion of Bogdan, Taylor, and Creswell mentioned above is that qualitative research is a collection of information in which characteristics are in the form of words and not a series of numbers. Qualitative research intends to understand the phenomena experienced by 
research subjects, for example, behavior, perception, motivation, action, etc., and holistically by using descriptions in the form of words and language in a special natural context and by utilizing various natural methods.

\section{Results and Discussion}

\section{Integration of Guidance and Counseling in Islamic Da'wah}

Guidance and counseling are branches of social science, which seems to be continuously developed into an independent discipline. Ontologically, the existence of guidance and counseling disciplines occupies a specific area of the human relationship in terms of the relationship that needs and helps each other (the helping relationship). Relationship patterns like this, in reality, are built by a person or group of people based on different motives and values. One of them is the foundation of religious spirit or elan vital in the form of awareness of the sacred mission as the basis for one's activities in establishing relationships with other people. On this basis, the existence of guidance and counseling activities is very appropriate to be integrated with Islamic da'wah activities. The existence of the guidance and counseling activities is based on the fact that in facing and solving problems, there are individuals who are able to solve their own problems, and some need help from other parties. In general, this assistance is sometimes called guidance or counseling (Komarudin, 2008).

For more details, the following researchers propose some understanding of guidance and counseling. Guidance in English is called guidance, coming from the verb "to get" which means to guide, show or guide others (Amin, 2010). Likewise, according to Arifin (1994), etymologically, guidance is showing, giving way, or guiding others towards goals that are beneficial to their lives in the present and in the future. The term "guidance" is a translation of the English word "guidance" which comes from the verb "to guide" which means "to show". Referring to the literature, there are a large number of limitations put forward by experts regarding the notion of guidance, in which in fact the differences stem from various aspects of different emphases. Shertzer and Stone (1980) formulate guidance as the process of helping individuals to understand themselves and their world (Ojo \& Rotimi, 2006). Jones (1970) states: 
Agus Riyadi \& Hendri Hermawan Adinugraha

JAGC | 16

"Guidance is the help given by one person to another in making choices and adjustments and in solving problems. The guidance aims at aiding the recipient to grow in his independence and ability to be responsible for himself. It is a service that is universal not confined to the school or the family. It is found in all phases of life in the home, in business and industry, in government, in social life, in hospitals, and prisons; indeed it is present wherever there are people who need help and wherever there are people who can help".

The Jones' formula above contains four things, namely 1 ) the help provided by a human being to another human being, 2) the help to make choices and adjustments as well as to solve problems, 3 ) the existence of a goal, including to help a person so that he can grow independently so that eventually he can take responsibility, and 4) actually guidance is everywhere, provided if there is someone who needs help and there is also someone who can help him.

According to Crow \& Crow (1960), guidance is defined as assistance given by qualified personality and adequately trained man or woman to an individual of any age to help him manage his own life activities, develop his point of view, make his own decisions, and accept and solve his own burdens.

Guidance is assistance provided by a person, both male and female who has a good personality and is adequately educated to an individual of every age in developing his own life activities to develop his own direction of view, making his own choices, and bearing his own burden. Failor (1957), one of the guidance and counseling experts in the school environment defines guidance as follows:

"Guidance services assist the individual in the process of selfunderstanding and self-acceptance, appraisal of his present and possible future socio-economic environment and in integrating these two variables by choices and adjustments that further both personal satisfaction and socio-economic effectiveness".

Guidance is assistance to a person in the process of understanding and accepting the reality that exists in himself as well as calculating (assessing) his present and possible future socio-economic environment and integrating these 
two things through the choices and adjustments that bring to the satisfaction of personal life and to the efficiency of social and economic life.

Based on the above opinions, it can be concluded that guidance is a process of providing assistance to individuals continuously, so that the individual can understand himself, and be able to direct himself and act naturally, in accordance with the demands and conditions of the school environment, family, and community. Guidance is the provision of assistance given to individuals to overcome various difficulties in their lives so that the individuals can achieve their welfare.

The term "counseling" is etymologically derived from the Latin word "concilium" which means "with" or "together" coupled with "accept" or "understand". Whereas in Anglo-Saxon, the term counseling comes from "sellan" which means "to submit" or "deliver" (Prayitno and Amti, 2014). Shertzer and Stone (1980) argue that counseling is an interactive process that facilitates a meaningful understanding of self and environment and results in the establishment, and or clarification of goals and values for future behavior. Based on the above definitions, Shertzer and Stone view counseling as a process of interaction by providing various facilities to form a meaningful understanding of individuals and their environment, resulting in a firm stance and/or clarity of goals to be achieved and the values adopted to be reflected in future behavior. Hoffman (1959) argues that counseling is:

"Counseling is the face-to-face meeting of counselor and counselee. Within the guidance services, counseling may be thought of as the core of the helping process, essential for the proper administration of assistance to students as the attempt to solve their problems. However, counseling cannot be adequate, unless it is built upon a superstructure of preparation".

Hoffman (1959) clearly describes that in counseling there is a face-to-face meeting between the counselor and client or counselee, and the counseling is seen as the essence or substance of the process of providing essential assistance for guidance service efforts to students when they try to solve their problems faced. However, counseling is considered inadequate if it is not formed on the basis of 
Agus Riyadi \& Hendri Hermawan Adinugraha

JAGC | 18

preparation and structured in an organizational structure. Therefore, Rogers (1962) emphasizes more on "regular and permissive relationships" in his view. He states, "Counseling is a very permissive relationship in which the client or counselee finds an opportunity to learn freely and safely regarding the difficulties and attitudes that undermine him".

Hana (1959) explains that counseling intends to provide services or information to a person in a process of meeting between two people, one of whom experiences shock caused by personal problems that cannot be solved by himself. Likewise, Tolbert (1972) argues:

"Counseling is personal, face to face relationship between two people in which the counselor, by means of the relationship and his special competencies provides a learning situation, in which the counselee, a normal sort of person is helped to know himself and his present and possible future situation so that he can make use of characteristics and potentialities in a way that is both satisfying to himself and beneficial to society and further can learn how to solve future problems, and meet future needs".

It is clear that counseling is carried out in a personal relationship through faceto-face activities between a client or counselee and a potential and professional counselor. The counseling process provides a learning situation for the client or counselee to help him understand himself, his current state, the possible future conditions that can be created using his potential, for the benefit of his personal and social. Next, he can learn how to solve his problems and at the same time find a way to meet his needs in the future.

Furthermore, Mortensen and Schmuller (1976) state, "Counseling may therefore be denned as a person to person process in which one person is helped by another to increase in understanding and ability to meet his problem". In this case, Mortensen and Schmuller see that in counseling there is an interpersonal process, one of which is assisted by another to increase understanding and skills in finding life's problems, and then to help him to make choices and make the right decisions to solve problems. Jones (1970) also states as follows: 
"Counseling denotes a professional relationship between a trained counselor and client. This relationship is usually person to person, although it may sometimes involve more than two people, and is designed to help the client understand and clarify his view of his lifespace so that he may make meaningful and informed choices consonant with his essential nature in those areal where choices are available to him".

Referring to the above opinion, Jones states that in counseling there is a professional relationship between a trained counselor and a client or counselee. He says that the relationship is usually individual, although sometimes it involves more than two people. The relationship is designed to provide assistance to the client or counselee in understanding and clarifying views on the scope of his life so that he can succeed in making meaningful and adequate choices for himself.

The analysis of Jones' opinion above produces a summary of important factors in counseling, including 1) Counseling is related to the goal of helping others to determine their choices and actions. 2) In the counseling process, a learning process occurs. 3) In the counseling process, personality changes and developments occur. Thus, counseling can be confirmed by the following formulations: 1) Counseling is carried out in a face-to-face relationship between two people (counselor and client orcounselee). 2) Counseling is done by people who are experts (with special abilities in the field of counseling). 3) Counseling is a vehicle for the client's or counselee's learning process, namely learning to understand oneself, making plans for the future, and overcoming problems at hand. 4) Self-understanding and planning for the future are done using the client's or counselee's own strengths. 5) The results of counseling must be able to create welfare, both for the client or counselee and the community.

The existence of attempts to design relationships in the counseling process, as stated by Jones above, is also supported by the opinion of Patterson (1967) with the use of psychological methods, in which he defines counseling as follows:

"Counseling is the process involving the interpersonal relationship between a therapist and one or more clients by which the former employs psychological method based on systematic knowledge of 
Agus Riyadi \& Hendri Hermawan Adinugraha

human personality in attempting to improve the mental health of the latter."

Complementing the previous opinion expressed by Jones in the above opinion, JAGC | 20 Patterson views that the interpersonal relationship between the counselor and the client or counselee, both individually and in groups, needs to be established by applying psychological methods based on systematic knowledge of human personality, in an effort to foster healthy mental. Furthermore, Patterson states that the importance of using psychological methods as a systematic way of finding the relationship between the client's or counselee's personality and the problems they face is to find solutions, for the sake of mental health development.

Counseling expressed in the above definition includes all forms of relationship between two people (counselor and client or counselee). The client or counselee is helped to be more able to adjust effectively to himself and his environment. This relationship atmosphere includes the use of interviews to obtain and provide a variety of information, train and teach, increase maturity, and provide assistance through decision-making and therapy or healing efforts. The term counseling also has a broader meaning and covers more specific fields, such as mental health development efforts, as an effort to provide psychic therapy. Likewise, in education, the client or counselee is hoped to handle difficulties which include weaknesses in skills, study habits, and emotional problems.

Thus, it is clear that counseling is an effort to carry out the following activities simultaneously: 1) Carrying out a counseling process or counseling steps. 2) Carrying out a help process, which includes efforts to understand the problems or needs of the client or counselee and provide assistance. 3) Organizing communication (between counselor and client or counselee). 4) Conducting interviews, observing, and listening (Moore and Roberts, 2010).

All of the above activities are carried out in an integral manner, mutual support used for the smooth running of the counseling process and the achievement of counseling objectives. By referring to the definitions stated by Shertzer and Stone and Patterson above, it can be concluded that counseling is a process of providing assistance services that provide convenience based on personality psychology 
theories, methods, and techniques to strengthen or clarify the client's values and future behavioral goals.

On the basis of the above theories, some of the characteristics of counseling are clear, including: 1) Counseling is a process that occurs because of a relationship between the counselor and a client or counselee or more, deliberately achieving a meaningful goal for the client or counselee. 2) Counseling is assistance so that the client or counselee is able to understand himself and his environment better to plan a better future. 3) In the counseling process, the counselor provides psychological value facilities for the client or counselee which are extracted from theories, methods, and techniques of personality psychology, and other social sciences to enable the client or counselee to change behavior from less positive to more positive. 4) The results to be achieved jointly by the counselor and the client or counselee are the manifestation and/or clarity of the values and behavioral goals of the client or counselee in the future, which is to make themselves and their communities happy (Pope and Vasquez, 2007).

Besides, Pietrofesa emphasizes that essentially, he believes that counseling can be described as the process through which a person professionally is prepared to counsel attempts to help another person in a matter of self-understanding, decision making, and problem-solving. Counseling is a face-to-face human encounter in which its outcome is greatly dependent upon the quality of the counseling relationship.

According to Pietrofesa (1978), in counseling, there is a process of having a person who is professionally prepared to help others to be able to understand themselves, make decisions, and solve problems. This process takes place with face-to-face contact in a heart-to-heart meeting between people in which the results depend on the quality of the relationship in question.

Further, the definition of counseling can be clarified as follows: 1) Counseling is a professional service provided by authorized counselors. 2) Counseling is a process that occurs on the basis of the counselor-client or counselee relationship. 3) Counseling is dealing with decision-making and problem-solving skills. 4) Counseling makes the client or counselee learn new behavior or attitudes. 5) 
Agus Riyadi \& Hendri Hermawan Adinugraha

JAGC | 22

Counseling is a joint effort of two parties (counselor and client or counselee), and is based on respect for the individual). 6) Counseling cannot be strictly limited because it is dynamic, but there are skills commonly used for such assistance relationships. 7) Counseling is a view of life (a way of life) (Shorrock, 2008).

Furthermore, some of the characteristics contained in the boundaries of counseling stated by Patterson, as quoted by Shertzer and Stone (2004); Kauffman and New (2004) are as follows: 1) Counseling is concerned with influencing voluntary behavior change on the part of the client (client wants to change and seeks counselor's help to change). 2) The purpose of counseling is to provide conditions that facilitate voluntary change (conditions such as the individual's right to make choices, to be independent and autonomous). 3) As in all relationships, limits are imposed upon the counselee (limits are determined) by counseling goals which in turn are influenced by counselor's values and philosophy. 4) Conditions facilitating behavioral change are provided through interviews (not all interviews are counseling but counseling always involves interviews). 5) Listening is present in counseling (but not all listening is counseling). 6) The Counsellor understands the client. 7) Counseling is conducted in privacy and discussion is confidential. 8) The client has a psychological problem and the counselor is skilled in working with clients who have psychological problems.

The characteristics contained in the limitation of counseling as stated above are: 1) Counseling is related to efforts to influence changes in most of the client's or counselee's behavior voluntarily (the client or counselee wants to change and get the counselor's help). 2) Counseling intends to provide conditions that are able to facilitate changes (such conditions in which an individual obligates to determine the right choice to be independent and gain self-confidence). 3) The client or counselee has a limit of motion in accordance with the counseling goals that he specifically sets together with the counselor at the beginning of the counseling process (the motion limit is determined by the counseling goals, which in turn is influenced by the counselor's values and life philosophy). 4) Conditions that facilitate changes in behavior are carried out through interviews (not all interviews are counseling, but counseling is always related to interviews). 5) Listening occurs in counseling (but not all counseling processes take place in a listening atmosphere 
only). 6) The counselor understands the client or counselee. 7) Counseling is carried out in a private setting and the results are kept confidential. 8) The client or counselee has psychological problems and the counselor has the skills and expertise to help to solve the problems.

Guidance and counseling are meant to be Islamic, so it is better if the word JAGC | 23 Islam is explained first. Usually, the word Islam is translated as "submission of oneself", surrender to God or even surrender (Arkoun, 1996). Ali (1990) states, "Islam has a two-fold significance: a simple profession of faith- a declaration that "There is no god but Allah and Muhammad is His Messenger" (Kalimah) and a complete submission to the Divine will which is only attainable through spiritual perfection" (Islam is (1) uttering the kalimah Shahada, namely "There is no God but Allah and Muhammad is His Messenger"; (2) fully surrendering to the will of Allah which can only be achieved through spiritual perfection).

Based on the above definition of Islam, what is meant by Islamic guidance and counseling is the process of providing assistance to individuals to be able to live in harmony and harmony with Allah's provisions and instructions, so that people can achieve the joy of life in the world and the hereafter (Dwairy, 2000; Faqih, 2000). Islamic guidance and counseling is an effort to assist individuals in overcoming deviations based on the development of their religious nature so that they rerealize their role as caliphs on earth, and function to worship and serve Allah so that ultimately a good relationship is created with Allah, others, and nature ( Ali, et al. 2005; Sutoyo, 2007).

It can also be said that Islamic guidance and counseling is an activity of giving advice (suggestions) in the form of communicative talks between counselor and client caused by the client's lack of knowledge (Adz-Dzaky, 2003; Saleh, 1987). Islamic guidance and counseling is a motivational process for individuals (humans) to have the awareness to "come back to religion", because religion will provide enlightenment for their attitudes, thoughts, and behavior towards a personal and social life that is sakinah, mawaddah, rahmah, and ukhfuwwah, so that humans will be avoided from unhealthy mental, or individualistic traits, exploitative passions that cause havoc on earth (Yusuf and Nurihsan, 2008). 
Agus Riyadi \& Hendri Hermawan Adinugraha

Akhyar (2007) formulates Islamic guidance and counseling as an assistance service to clients for:

a) Knowing, recognizing, and understanding the situation according to its nature.

JAGC | 24

b) Accepting their condition as there are good and bad aspects, strengths, and weaknesses as something that Allah SWT determines so that awakens people to make efforts and put their trust in solving all their problems.

c) Understanding the circumstances (situations and conditions) that they face. In this case, it is helped to formulate problems, diagnose, and find alternatives to the problems that they face.

Arifin (1987) states that the purpose of Islamic guidance and counseling is to help clients to have a religious reference in solving problems and to help clients with their awareness and willingness to practice religious teachings. From these various definitions, it can be concluded that Islamic guidance and counseling is the provision of assistance to individuals to develop all their nature to face their problems in accordance with the guidance of Islamic teachings.

Based on the above understanding, it seems clear that, there are differences and similarities regarding the meaning of guidance and counseling. The difference in the meaning of guidance and counseling can be explained as follows. The first opinion considers that counseling is part of the guidance, namely technical guidance. The second opinion says that the difference between guidance and counseling lies in the center of its attention. If guidance focuses on preventing problems faced by individuals, counseling focuses on healing individuals from the psychological problems that they are suffering from. It can also be said that the problems handled by the guidance program are lighter, while severe problems must be handled with counseling. In certain cases, counseling may even need to be transferred to other experts, such as psychotherapy. However, the objects of guidance and counseling are the same, namely psychological problems. If there are patients who suffer from psychological and physical problems at the same time, then the treatment must be differentiated, the physical problem is submitted to the medicine, then the psychological problem is handled by a guidance and 
counseling program (Mubarok, 2000; Musnamar, 1992; Basit, 2006; Komarudin, et al., 2008).

Concerning the similarities of guidance and counseling, it can be concluded that both are interpreted as a process of interaction that is equally aimed at providing assistance to other parties. Besides, the assistance process is carried out by an expert. The process of providing assistance is intended so that people who receive assistance have the ability to develop their own abilities independently so that the problems faced can be resolved. Also, the process of providing assistance provided by an expert has the same function, namely preventive, curative (corrective), preservative, and developmental functions. Furthermore, the subjects who are given guidance or assistance sometimes consist of one person or several people (groups). However, in the "counseling" process, there are several characteristics that are not found in the "guidance" process in general. The characteristics referred to are the "counseling" process which is largely determined by the setting in which a person carries out the guidance practice, the type and method of services provided, and the level of training received by an expert.

However, it is not appropriate if based on such characteristics, then the counseling process is distinguished absolutely (antagonist-diametral) from the guidance process. Perhaps it is most appropriate to make a comparison between the counseling process and other forms of the helping relationship, such as psychological therapy. Therefore, the relationship between guidance and counseling is more accurately described as the relationship between subject and branch. Or, in other words, that counseling is a form of guidance or assistance services, and the existence of which is distinguished from various other types of services or assistance. On the basis of this kind of thinking, the term guidance and counseling should also be referred to as counseling guidance (Komarudin, 2008).

\section{Applied Da'wah Science}

This form of activity that invites mankind to al-Islam, can be carried out in an oral or written way (da'wah bi al-lisan and bi al-qalam) and can also be done by deeds (da'wah bi al-hal or Islamic social action (bi ahsan al-amal) ), as well as can be carried out by organizing and managing inviting activities (bi al-lisan, bi al-qalam, 
Agus Riyadi \& Hendri Hermawan Adinugraha

JAGC | 26

and bi al-hal) in the form of Islamic institutions as da'wah institutions that systematize actions, coordinate, synchronize, and integrate program activities with resources and the time available to achieve the goals and objectives of Islamic preaching (Enjang, and Aliyudin, 2009).

The da'wah science can be categorized into two categories: theoretical da'wah science, which is one of the da'wah disciplines that seeks to provide a theoretical framework and methodology for Islamic da'wah, and applied da'wah science (da'wah technology), which is a discipline of da'wah that seeks to provide an operational technical framework of Islamic da'wah activities. According to Sambas, as quoted by Sulthon (2003) applied da'wah science consists of four sub-disciplines, namely Islamic tabligh science (Islamic Communication and Broadcasting), Ershad science (Islamic Counseling Guidance), tadbir science (Da'wah Management), and tathwir science (Community Development). Within each of these sub-disciplines, several concentrations are developed. The science of Tabligh includes: (Khithabah Studies, Da'wah Press Studies, Radio Da'wah Studies, TV Da'wah Studies, and Da'wah Film Studies). The Irsyad sub-discipline develops the following concentrations: (Islamic Guidance Studies, Islamic Counseling Studies, and Islamic Psychotherapy Studies). The Tadbir sub-discipline develops the following concentrations: (Management Studies and Da'wah Organization, Bank Management Studies, and Islamic Economics). The Tathwir sub-discipline develops the following concentrations: (Muslim Community Development Studies, Community Economic Development, and Environmental Resources Development). In fact, the concentration of studies developed by each department in the da'wah faculty throughout Indonesia is not the same.

Similar opinions are expressed by Enjang and Aliyudin (2009); Sambas in Kusnawan (2004) who state that da'wah bi al-lisan (speech) / bi al-qalam (writing) becoming fundamental theory to aspects of special activities consisting of:

1) Study of issues related to Tabligh, namely Islamic Broadcasting Communication (KPI). The dimensions of Islamic communication and broadcasting activities have a mass target based on the pattern of problem tendencies that develop in society in general in all aspects of life which have 
an impact on the direction of system development and the life history of congregations or Muslims.

2) Study of problems related to Ershad, namely Islamic Counseling Guidance (BPI). The dimensions of Islamic guidance and counseling activities are targeted at individuals and small groups on the basis of special problems (casuistic) in all life that have an impact on the lives of individuals and families.

While the preaching of bi al-hal becoming fundamental theory to a special study consisting of:

1) Study of problems related to tadbir, namely Da'wah Management (MD). This dimension is an organizational aspect of da'wah activities which includes the management of the da'wah activities itself by developing and empowering Islamic institutions.

2) Study of problems related to tathwir, namely (Islamic Community Development); is a real action system that offers an alternative model of solving the problems of the Ummah in the social, economic, and environmental fields based on an Islamic perspective. In other words, the dimensions of the development of Muslim life are in the aspect of universal culture, namely the transformation of Islamic teachings through righteous deeds in the form of empowering human resources and environmental resources.

At least the four forms of da' wah activities above and the problems are aspects that are studied intensively by the science of da' wah as part of its formal object.

\section{NSQ (Al-Nadzariyah Al-Syumuliyah Al-Qur'aniyah) Perspective}

Kerlinger (2005) suggests that a theory is a set of interrelated constructs (concepts), definitions, and propositions that present a systematic view of phenomena by specifying relations among variables, with the purpose of explaining and predicting the phenomena (theory is a set of constructs (concepts), definitions, and propositions that function to see phenomena systematically, through the specification of the relationships between variables, so that they can be useful for explaining and predicting phenomena). Theory, as referred to in the 
Agus Riyadi \& Hendri Hermawan Adinugraha

JAGC | 28

ushul or principal (a form of reality) above is built through epistemology, namely the method of acquiring knowledge that is rooted in aspects of its philosophy. The root of this Islamic da'wah methodology is al-nadzariyah al-syumuliyah alquraniyah (holistic thinking based on the guidance of the Qur'an) which is then called the NSQ. The operation of the NSQ combines al-madzhab al-nadzariyah alma'rifah (the theory of science). In other words, it integrates the method of acquiring knowledge as shown by the Qur'an. Meanwhile, the partial theory of knowledge includes: (1) al-mazhab al-tajribi (empiricism), (2) al-madzhab al-aqli (rationalism), (3) al-madzhab al-naqdi (criticism), and (4) al-madzhab al-shufi (mysticism).

The primary reference of this NSQ is Q.S. al-Isra verse 36:

"And do not pursue that of which you have no knowledge. Indeed, the hearing, the sight, and the heart-about all those [one] will be questioned".

In addition, Q.S. Ali-Imran verse 18:

"Allah witnesses that there is no deity except Him, and [so do] the angels and those of knowledge - [that He is] maintaining [creation] in justice. There is no deity except Him, the Exalted in Might, the Wise".".

This NSQ work model can be formulated as a conceptual process of preaching reality through the use of the sharpness of the potential senses, reason, and heart in upholding rights and justice (proportional scientific truth). This process becoming fundamental theory to a number of scientific propositions of da'wah which are manifested in a discipline of da'wah.

This NSQ model shows the scientific work process of Islamic da'wah, namely the da'wah science explaining the essence of da'wah which comes from the Qur'an, sunnah, history, and reality, through the use of the born senses in the form of observation, the use of reason in the form of reasoning, and the use of the heart in the form of application. This work product becomes the discipline of Da'wah Science. Furthermore, the NSQ has conceptual working rules as follows:

1) Not going beyond the object of reasoning ('adam tajawq al-had)

2) Provisioning and determining the object of discussion (al-taqdir wa al-taqrir) 
3) Barring something before being studied (al-takhsish qabl al-bahts)

4) Not being arrogant and denying the truth ('adam al-muakabarah wa al-inad)

5) Adhering to the image and submitting to its accuracy (al-muraja'ah wa almu'awadah)

6) Sticking to the truth (al-istimsak bi al-haq)

7) Keeping away falsehood (al-bu'du an al-ghurur)

8) Upholding the truth (al-jahr al-haq)

9) Calling out the truth (al-da'wah ila al-haq)

10) Maintaining the truth (al-difa ila al-haq).

The following image shows the NSQ work process:

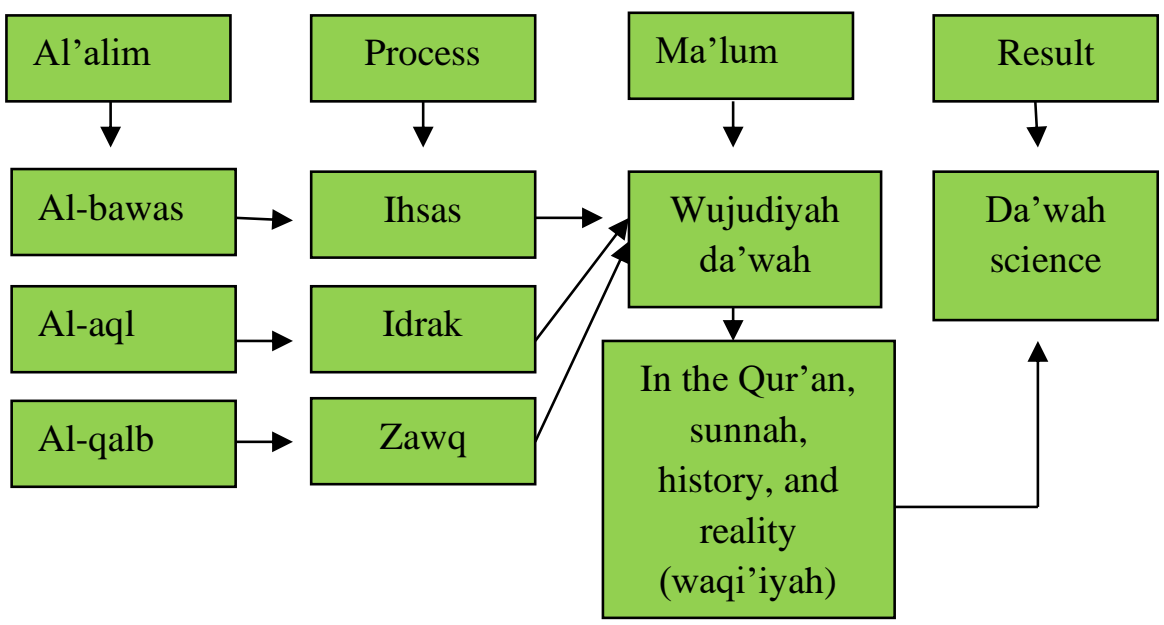

Figure 1. NSQ work process

NSQ actualization is operationally referred to as Da'wah Science, as a logical epistemological consequence, namely: (1) manhaj istinbath, (2) manhaj iqtibas, and (3) manhaj istiqra '(hereinafter, these three methods are called Mla, Mlb, and Mlc). The conceptual definition of Mla is the process of reasoning (istidhlal), in understanding and explaining the nature of da'wah by taking lessons from social science theories, such as sociology, psychology, anthropology, and others. Mlc is a 
process of reasoning (istidhlal) in understanding and explaining the nature of da'wah through qualitative research by referring to the product theory of Mla and Mlb.

JAGC $\mid 30$

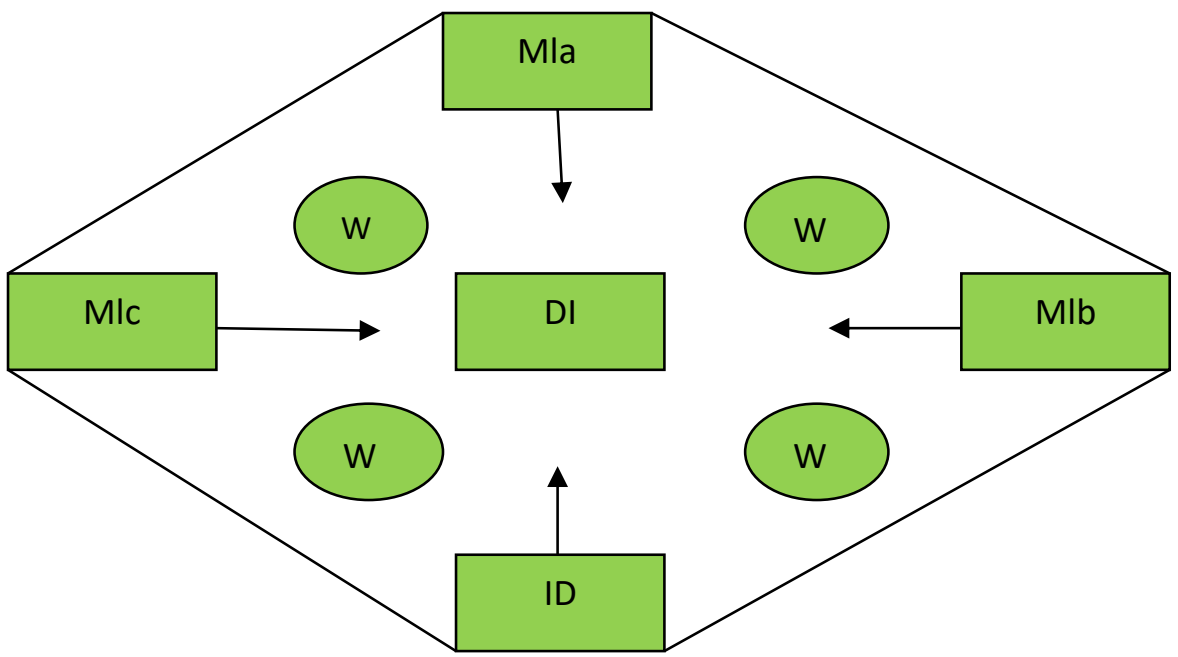

Figure 2. Logical epistemological

Description:

Mla = Product: the main theory (grand theory)

$\mathrm{Mlb}=$ Product: intermediate theory

Mlc $=$ Product: small theory

$\mathrm{DI}=$ The essence of Islamic Da'wah

$\mathrm{ID}=$ Scientist: Actors of Mla, Mlb, and Mic

$\mathrm{W}=$ Region

\section{Islamic Counseling Guidance in the Structure of Da' wah Science}

Da'wah encourages people to do good according to instructions, calls on them to do good, and prohibits them from evil deeds, so that they can get happiness in the world and the hereafter (Mahfuz, 1979; Taimiyyah). Islamic da'wah with all its activities has been developed from time to time. This development can be seen from the material that is contextualized with the times, methods, and others, especially in the context of renewal which has recently been echoed in the context of Islamic revival. Departing from the starting point of inviting humans who are done verbally (da'wah bi al-lisan), by deed (da'wah bi al hal), by writing (da'wah bi 
al tadwin) regarding prevention, problem handling, healing (cure), and development ( $\operatorname{mad}^{\prime} u$ ), various sciences are applied in Islamic Da'wah in order to achieve goals, including guidance and counseling, where this knowledge is adapted to Islamic teachings. Islamic guidance and counseling will be very helpful in optimizing the purpose of da'wah, including by providing preachers with Islamic knowledge based on Islamic guidance and counseling, so that in the implementation of da'wah, whenever there are obstacles related to one's psychological condition, then the obstacles will be easier to overcome (Murtadho, 2004).

In the Qur'an and Hadith, there are many verses that are substantially, closely related to the basic principles of values, philosophy, and the implementation of guidance and counseling, for example regarding human nature, healthy personality, unhealthy personality, the concept of counseling, the role and function of the counselor, and the techniques and procedures in counseling. This is very natural because Islam is not anti-science at all. On the other hand, it is precisely when these Islamic values are used as the basis for the development of a science that it will provide the spirit of morality and spirituality for the related science. Therefore, of course, the process of implementing Islamic counseling guidance cannot at all be separated from the ethical principles of preaching in Islam, which refers to the ethical foundation of preaching of bi al-hikmah, al-maudhah alhasanah, dan al-mujadalah bi allati hiya ahsan.

The essence of God's voice written in the Qur'an, is the essence of Islamic da'wah, because the Al-Qur'an speaks of aqidah, worship, and mu'amalah (Qutub). Thus, the focus of Islamic missionary is to give understanding to mankind to practice the teachings of Allah contained in the Al-Qur'an al-Karim as a way of life. The teachings of Allah were synthesized from the Al-Qur'an consisting of "aqidah" and "syari' ah", or in other terms "faith" and "righteous deeds" (Hasjimi, 1994). The reality shows that the problems faced by the Muslim community are increasingly complex. For this reason, the preachers are required to be able to read preaching messages according to the development of the society that they are facing. Thus, the existence of da'wah remains an option to improve mad'u life, as well as having the power to solve the problems. Among other things, the preaching language can 
Agus Riyadi \& Hendri Hermawan Adinugraha

be voiced through Islamic guidance and counseling, namely by collaborating the da'wah model into Islamic guidance and counseling. The implementation of da'wah through guidance and counseling can be done well if a preacher raises awareness to internalize the values of Islamic teachings in mad'u individually, is able to establish good personal relationships, is oriented towards problem-solving, conveys pre-programmed messages, and oriented to the set targets (Bukhori, 2014).

Guidance and counseling or what is commonly referred to as BK / BP is initially used more in the world of education, namely the knowledge needed to help students who experience learning difficulties caused by mental disorders. Conceptually, the Department of Educational Psychology at the Faculty of Education and Teacher Training is expected to produce teachers who are able to provide guidance and counseling services to students' problems. Within the Faculty of Islamic Religion, especially in the da'wah science departments, Islamic or religious guidance and counseling is a form of da' wah aid. The university students can deliver da'wah knowledge, namely the knowledge that talks about how to preach among problematic mad'u, namely people who suffer from mental disorders. The object of preaching in this sense is an individual, not a mass audience, because the problems of people with mental disorders are owned by an individual and must be handled one by one. On the other hand, Islamic guidance and counseling can also be included in applied mental sciences; namely the Psychology of Da'wah.

If the science of da'wah talks about the components of da'wah (da'i, mad'u, messages, and methodology), the psychology of da'wah is regarding exposing the inner atmosphere of human behavior involved in the da' wah process (da'i mad'u) so that da'i can describe, predict, and control the behavior of mad'u in general so that the preaching becomes effective. Thus, Islamic guidance and counseling is needed to preach to people who are experiencing psychological problems, namely helping them to re-discover themselves with the potential of their faith so that they can overcome the difficulties at hand. Actually, the work of providing Islamic guidance and counseling services has been done by many preachers or muballigh and kyai, but because they do not depart from the concept of guidance as a 
scientific discipline, the guidance and counseling techniques and procedures are carried out improvisedly, and are generally not recorded.

What provided by the kyai is in providing Islamic guidance and counseling services may be more effective than what professional counselors do. But because there is no written data, the experience of the kyai does not contribute adequately to the development of the discipline of Islamic guidance and counseling. With the help of Islamic guidance and counseling, it is possible for kyai or religious teachers and preachers to work professionally, and to not rule out the possibility of enriching their scientific knowledge, and emerge new theories in the field of guidance and counseling. Kyai and preachers can be involved or encouraged in professional guidance and counseling service programs, responding to the growing needs of society. Da'wah institutions as well as Islamic boarding schools can open counseling clinics with adequate facilities. In today's global society, especially in big cities, guidance and counseling services can also be provided by telephone, post, or special sections in newspapers and magazines.

Regarding Islamic guidance and counseling, there are two things that need to be considered in the scientific construction of Islamic Counseling Guidance, namely the counselor aspect and aspects of Islamic values which are used as the basis for the counseling guidance professional activities. Based on the object of form, the aspect that distinguishes between counseling in general and Islamic counseling only lies in the status of the counselor and the normative values which are used as the basis for counseling guidance service activities. However, the difference in normative values which is used as the spirit of morality in the activities of the Islamic counseling guidance service does not have to have a logical consequence in which ontologically Islamic counseling is absolutely different from other counseling services in general. The presence of Islamic counseling, and its existence, can be aligned horizontally, and also compared, with the existence of various counseling disciplines developed by other scientists (Komarudin, 2015; Himawanti et al, 2020).

Related to the da'wah science, the structure of the da'wah science is constructed based on the very multidimensional relationship between ontological, epistemological, and axiological elements. Ontologically, the object of study includes both abstract and concrete dimensions. Meanwhile, epistemologically, 
da'wah does not have a specific and independent method. It depends a lot on and borrows the methods of other sciences. Then, axiologically, da'wah has a religious subjective-emotional orientation and an objective-scientific orientation at the same time. This means that functionally da'wah has the opportunity to become a science with both applied and theoretical typology. On that basis, da'wah science can be called a scientific discipline with interdisciplinary and multidisciplinary characteristics. It is called interdisciplinary because the da'wah science is inseparable from the contribution of other related sciences, such as Knowledge of Akhlaq, Knowledge of Tafsir, Science of Hadith, Science of Figh, Science of Kalam, and Islamic History as categorized in the religious sciences. Meanwhile, it is called multidisciplinary, because the structure of Da'wah is inseparable from the contribution of other sciences that are not allied, but having relevance toward efforts to explain the various realities of da'wah activities, including Sociology, Anthropology, Management Science, Psychological Science, Political Science, and others as categorized in the Social Sciences.

\section{Conclusion}

Guidance and counseling are branches in social science, which seem to be continuously developed into an independent discipline. Ontologically, the existence of guidance and counseling disciplines occupies a specific area of the human relationship in terms of the relationship that needs and helps each other (the helping relationship). Relationship patterns like this, in reality, are built by a person or group of people based on different motives and values. One of them is the foundation of religious spirit or elan vital in the form of awareness of the sacred mission as the basis for one's activities in establishing relationships with other people. On this basis, the existence of guidance and counseling activities is very appropriate to be integrated with Islamic da' wah activities so that it becomes clear that the construction of Islamic guidance and counseling is in the structure of da'wah science. 


\section{References}

Achmad, A. (1983). Dakwah Islam dan perubahan sosial. Seminar nasional dan diskusi Pusat Latihan, Penelitian dan Pengembangan Masyarakat (PLP2M). Prima Duta.

Adz-Dzaky, M. H. B. (2002). Konseling \& psikoterapi Islam: penerapan metode sufistik. Fajar Pustaka Baru.

Akhyar, S. (2016). Konseling Islam: Kyai dan pesantren. elSAQ Press.

Ali, M. M. (1990). The religion of Islam, The Ahmadiyya Anjuman Ishaat Islam Lahore.

Ali, O. M., Milstein, G., \& Marzuk, P. M. (2005). The Imam's role in meeting the counseling needs of Muslim communities in the United States. Psychiatric services, 56(2), 202-205. https://doi.org/10.1176/appi.ps.56.2.202.

Amin, S. M. (2010). Bimbingan dan konseling Islam. Amzah.

Arifin, M. (1987). Pokok-pokok bimbingan penyuluhan agama (di sekolah dan di luar sekolah). Bulan Bintang.

Arifin, M. (2008). Psikologi da'wah. Bulan Bintang.

Arifin, M. (1994). Pedoman pelaksanaan bimbingan dan penyuluhan agama. Golden Terayon Press.

Arkoun, M. (1996). Rethinking Islam, Terj. Yudian W.Asmin, Lathiful Khuluq. LPMI bekerjasama dengan Pustaka Pelajar.

Basit, A. (2006). Wacana da'wah kontemporer. Pustaka Pelajar.

Bogdan, R \& Taylor, S. J. (1975). Introduction to qualitative research methods. John Wiley and Sons, Ltd.

Bukhori, B. (2014). Dakwah melalui bimbingan dan konseling islam. Jurnal Konseling Religi, 5(1), 1-18. http://dx.doi.org/10.21043/kr.v5i1.1057.

Creswell, J. W. (2015). Qualitatif inquiry and research design: Chosing among five appoaches, terj. Ahmad Lintang Lazuardi. Pustaka Pelajar.

Crow, L. D., \& Crow, A. (1962). An Introduction to guidance. Eurasia publishing house.

Dwairy, M. A. (2006). Counseling and psychotherapy with Arabs and Muslims: A culturally sensitive approach. Teachers College Press. 
Agus Riyadi \& Hendri Hermawan Adinugraha

Hoffman, A. E. (1959). An analysis of counselor sub-roles. Journal of Counseling Psychology, 6(1), 61. https://doi.org/10.1037/h0043985.

Enjang \& Aliyudin. (2009). Dasar-dasar ilmu da'wah pendekatan filosofis \& praktis. Widya Padjadjaran.

Failor, C. W. (1957). Nature and scope of guidance service. Mimeographed.

Faqih, A. (2000). Dasar-dasar bimbingan dan konseling islami. UII Press.

Hafidhuddin, D. (2009). Da'wah aktual. Gema Insani.

Hana, A. M. (1959). Asy-Syakhsiyyah wa as-Sihah an-Nafsiyyah. Maktabah anNahdhah al-Mishriyah.

Hasjimi, A. (1994). Dustur da'wah menurut Al-Qur'an, Bulan Bintang.

Himawanti, I., Hidayatullah, A., \& Setiyono, A. (2020). Happiness reconstruction through islamic guidelines in blinds in The Muslim Blinds of Indonesia (ITMI) Central Java. Journal of Advanced Guidance and Counseling, 1(1), 39-57. https://doi.org/10.21580/jagc.2020.1.1.5768.

Jones, A. J et al. (1970). Principles of guidance. McGraw Hill Kogakusha Company.

Kauffman, K \& Caroline, N. (2004). Co-counselling: The theory and practice of reevaluation counselling. Oxford University.

Kerlinger, F. N. (2005). Foundations behavioral research second edition. Rinehart and Winston, Inc.

Komarudin, K. (2017). Mengungkap landasan filosofis keilmuan bimbingan konseling Islam. International Journal Ihya"Ulum al-Din, 17(2), 209-232. https://doi.org/10.21580/ihya.16.2.1653.

Komarudin, et. al. (2008). Da'wah dan donseling Islam: Formulasi teoritis da'wah islam melalui pendekatan bimbingan konseling. Pustaka Rizki Putra.

Kusnawan, A. (2004). Ilmu dakwah (kajian berbagai aspek). Pustaka Bani Quraisy.

Mahfuz, S. Ali. (1979). Hidâyat al-Mursyidîn ilâ Thuruq al-Wa'zi wa al-Khitâbath. Dâr al-Kutub al-'Arabiyyah.

Moore, J \& Ruth, R. (2010). Counselling and psychotherapy in organisational settings. Oxford University.

Mortensen, D. G., \& Schmuller, A. M. (1976). Guidance in today's schools. John Wiley \& Sons, Inc.

Mubarok, A. (2000). Konseling agama teori dan kasus. Bina Rena Pariwara. 
Murtadho, A. (2004). Da'wah dengan pendekatan konseling islami perspektif sejarah dan budaya. Jurnal Ilmu Da'wah, 24(2).

Musnamar, T, (1992), Dasar-dasar konseptual bimbingan dan konseling Islami, UII Press.

Ojo, O. D., \& Rotimi, O. (2006). Fundamentals of guidance and counselling. Victoria Island, Lagos: National Open University of Nigeria. Available online also at: https://nou. edu. ng/sites/default/files/2017-03/EDU [accessed in Ilorin, Nigeria: April 15, 2019].

Patterson, C.H. (1967). Counseling and psychotherapy. Harper and Brothers.

Pietrofesa, J.J., et al. (1978). The Authentic counselor. Rand McNally College Publishing Company.

Pope, K. S., \& Melba J. T. V. (2007). Ethics in psychotherapy and counseling a practical guide, third edition, Oxford University.

Prayitno, E. A. (2014). Dasar-dasar bimbingan dan konseling, Rineka Cipta.

Quthub, S. Fî Zilâlil Qur' ân juz I. Ihyaut Turasil Araby.

Rais, A. (1999). Cakrawala Islam antara cita dan fakta. Mizan.

Rogers, C. R. (1962). Counseling and psychotherapy. Houghton Mifflin Company.

Saleh, M. A. (1987). Counseling and guidance in the Kingdom of Saudi Arabia. International Journal for the Advancement of Counselling, 10(4), 277-286. https://doi.org/10.1007/BF00121523.

Sanusi, S. Pembahasan sekitar prinsip-prinsip da'wah islam. CV.Ramadhani.

Shertzer, B., \& Stone, S. C. (1980). Fundamentals of counseling. Houghton Mifflin School.

Shorrock, A. (2008). The transpersonal in psychology, psychotherapy and counselling. Brigham Young University, Department of Counseling Psychology and Special Education, Provo, UT, US.

Sulthon, M., Dakwah, D. I., \& Ontologis, K. (2003). Epistemologis dan aksiologis. Yogyakarta: Pustaka Pelajar.

Sutoyo, A. (2007). Bimbingan dan konseling islam (teori dan praktek), Cipta Prima Nusantara.

Taimiyyah, S. I. Majmû'ah al-Fatâwa, Juz XV. al-Tab'ah al-Saûdiyah.

Tolbert, E.L. (1972). Introduction to counseling. McGraw-Hill. 
Agus Riyadi \& Hendri Hermawan Adinugraha

Yusuf \& Nurihsan. (2008). Landasan bimbingan dan konseling. Remaja Rosdakarya. Zahrah, A. (1994). Da'wah Islamiah. Remaja Rosdakarya.

JAGC | 38 